\title{
THE INFLUENCE OF SCHOOL ON THE REPRODUCTION OF EDUCATIONAL INEQUALITIES
}

\author{
E. Lavrentsova* \\ Faculty of Pedagogy, Trakia University, Stara Zagora, Bulgaria
}

\begin{abstract}
The paper addresses the problem of educational inequality and the new ways in which it is reproduced within the modern school education system. The sustainable character of educational inequality in Bulgaria is analyzed in the light of its institutional nature, which, despite the European membership of the country, shows a clear tendency towards intensification and reflects the growing social differences between the advantaged and vulnerable groups in Bulgarian society.

The intention of the author is aimed at comprehending some current limitations and opportunities for the action of teachers and school institutions, which are conditioned by the peculiarities of the contemporary economic, socio-cultural, and educational situation.
\end{abstract}

Key words: educational inequality, school institution, social selectiveness, socio-economic status

Key words: social stratification, society, inequality, class, power, status.

\section{INTRODUCTION}

Education is the key social institution that regulates the transmission of knowledge, cultural values and "identities" in society and determines the life trajectories of individuals. It is one of the central mechanisms for preserving social memory and social inheritance. In modern sociological research, however, education is seen not as a "social", and in this kind of thought expensive area of unproductive labor, but as a form of the most effective investment in "human capital" and therefore a sphere of highly competitive relations (1).

The level of education and the acquired qualification determine the degree of productivity of both the individual and the total human resources involved in the field of labor relations, and hence predetermine the subsequent opportunities for realization on the labor market from an individual perspective and effective economic development from the point of view of the functioning of the whole

*Correspondence to: Elena Lavrentsova, Faculty of Pedagogy, Trakia University, Stara Zagora, Bulgaria, elenavit@abv.bg, phone: (042) 613753 , mobil: 0889428490 society. Education influences economic processes in three directions: improves the general level of knowledge and skills among the population (human capital); provides the necessary capacity to develop technologies and implement innovations; provides transfer of new knowledge and ideas. It is the human and physical capital that the economy of each society has that constitutes its capacity for growth and competitiveness in the long run (2). Viewed in a broader perspective of the future development of labor activity, education is beginning to attract even more attention of various social actors. The rapid technological changes, the impending transition to a new phase in the development of the capitalist system - "cognitive capitalism" - lead to significant transformations in the appearance and nature of labor activities, the essence of labor in general. The establishment of a new era is publicly articulated - the "Fourth Industrial Revolution", the "Digital Age", or the "Second Age of Machines". This type of social organization obviously presupposes the realization of educational perspectives by expanding the processes of socialization of knowledge. The promotion of education in this context is seen as the main tool for increasing common well-being and eradicating poverty. 
It is through inclusion in education and real learning that children from disadvantaged groups of the population with low socioeconomic status are given the opportunity to experience upward social mobility. Raising education in the conditions of the modern high-tech society is essentially the only legitimate way which allows the achievement of a higher status in the system of division of labor and distribution of power.

But education in its specific institutional nature is not only the main channel for social mobility, which works as a socio-structural lift, it also serves as a form of reproduction of certain normative models and value patterns along with cultural, economic and political elite that supports them. Being deeply relevant to the general stratification system of society, education thus generates different configurations of inequality by regulating access to intellectual resources. The question here is how this stratification function inherent in education can meet new economic and public expectations related to the need for broader socialization of knowledge and the growing movement for equal opportunities for vertical mobility. In other words, how in the most consistent way can the deep-rooted aspiration for equality, for the egalitarian format of education within the new sociocultural situation be combined with the constant orientation of the educational system to the differentiation of the professional careers and social status?

Schools and teachers in the context of standardization and autonomy

In the last few decades, sociological science has managed to accumulate a significant number of conceptual models revealing the mechanisms and factors for the reproduction of inequality through education. In general, they can be grouped into two main areas, reflected respectively in the socialization model and the allocation model. According to the first approach $(3,4)$, vertical mobility in the field of education establishes an indirect influence of the socio-economic status on the intellectual development of the child. The value orientations and attitudes, formed mainly under the influence of the family environment, play a decisive role here. The social stratum is reproduced in the education system not so much through success but through a specific focus on achievement and a certain career trajectory. This approach refers to the prevailing perceptions, mainly in the $60 \mathrm{~s}$ and $70 \mathrm{~s}$ that education reinforces previously formed, already existing socioeconomic inequalities. In other words, not the peculiarities of the organization of the learning process, including its accessibility, but the students themselves through their behavior and activity reproduce and confirm their status characteristics and, accordingly, inequalities. $(5,6)$.

The second approach $(7,8)$ emphasizes that the individual is largely determined by social institutions: his/her achievements depend on the nature of the admission and a number of other conditions and regulations that these institutions establish. Achieving a certain level of education or status here is seen as subject to definite structural constraints and selective criteria used within the educational system. In recent years, this approach has become more widespread and popular, but it certainly does not exclude, but rather complements the first. Hence, in the field of scientific and public discourse, the question of the influence of various factors on the reproduction of educational inequalities is invariably raised, with increasing attention being paid to clarifying the role of the school, which covers both its institutional and structural dimension, and the subject-activity side in the face of the main educational actors - teachers and school principals. At the same time, this role, being contextually dependent, undergoes changes, adapting to the new economic and sociopolitical realities.

Thus, in the earlier stage of sociological research in the field of education (the 60s), the attention of scientists is focused on such aspects of the reproduction of inequality in the walls of the school and the classroom, which reflect the relationship between socio-class and ethnic origin of the representatives of the teaching staff and the methods, forms and technology of teaching used by them, the available educational practices, as well as the nature of the relationship: teacher - student. In addition, the specificity in the construction of the curriculum and assessment procedures, closely correlated with the cultural norms and value preferences of the middle class, is considered and emphasized.

Under the influence of these ideas many new training programs are developed and implemented, a serious "deconstruction" of the 
curriculum is undertaken, aimed at overcoming the gap between the teacher's expectations the principles, postulates, norms and techniques used by him/her in the educational work, which are based on the foundation of the dominant culture, and the specific canons of mentality, ways of perception and learning, inherent in children from the minority ethno cultural communities and reflecting the respective subcultural worlds.

Later, the focus of research interest began to concentrate on the study and analysis of internal factors related to the organizational structure and functioning of school institutions. A great number of research works on 'effective schools' has revealed, for instance, that some schools are more successful than others in assisting children to learn and that this 'effectiveness' is closely connected to certain organizational factors, including "clear school goals," "rigorous academic standards," "order and discipline," "homework," "clear leadership by the school principal," "teacher participation in decision-making," "parental support and cooperation" and "high expectations for students", the existence of teachers' collaborative cultures (9).

In additional, some research has also shown that effective schools support a collective ideology focused on learning and based on the belief that all children can and should have an opportunity to learn. In the frame of this intention, the positive role of students themselves is usually stressed upon: it can be implemented when students have high academic expectations and regard their classmates through a prism of academic criteria. These results have been applied to design the different kind of programmes and tools to help ineffective and less competitive schools with a high number of lower-class, migrant or ethnic minority students, improve their academic achievements and school performance.

The increased focus on learning as an opportunity to raise the effectiveness of education is associated with many recommendations for the development of education and educational policies worldwide. It is especially emphasized that schooling without learning is a wasted opportunity. More than that, it is a great injustice: the children whom society is failing most are the ones who most need a good education to succeed in life. There is a possibility to improve the learning process and its effectiveness by advancing on three fronts:

- Assess learning - to make it a serious goal. This means using well-designed student assessments to gauge the health of education systems learning measures to spotlight hidden exclusions, make choices, and evaluate progress.

- Act on evidence - to make schools work for all learners. Evidence on how people learn has exploded in recent decades, along with an increase in educational innovation. Countries can make much better use of this evidence to set priorities for their own practice and innovations.

- Align actors - to make the whole system work for learning. Countries must recognize that all the classroom innovation in the world is unlikely to have much impact if, because of technical and political barriers, the system as a whole does not support learning (10).

It is this kind of barriers or restrictions (not only technical or political ones) that a number of scientists make sense of. They reveal that there are essential limitations to improvement in problem schools and that pedagogical and organizational effectiveness are in fact strongly related to school intake or school-mix effects. It means that the concentration of academically and socially disadvantaged children in certain schools and in certain classes within schools tends to generate effects in terms of teaching and learning that cannot be totally, or even to a great extent, counteracted by professional involvement and organizational arrangements (11).

Competition and school segregation

The teachers' practices and ideological frames are beginning to change and modify in the context of school segregation. If in a heterogeneous environment teachers are usually oriented in their teaching to the 'average' student in accordance with a certain educational standard, in homogeneous, lowachieving schools or classrooms, they tend to adapt to specific student intake, offering a more limited curriculum and not so demanding evaluations of student's work. Based on this, they start to develop a special professional attitude related to the reorientation from the instrumental approach of assessment to the emotional-expressive manner of communication and teaching with an emphasis on rather social and emotional well-being and 


\section{LAVRENCOVA E.}

personal support of students from vulnerable groups.

Segregation among schools, partly the consequence of the urban segregation patterns and parental school flight evoked before but also resulting from competition among schools, is thus an essential factor to be taken into account. This competition is related to increasing school autonomy, which, in the absence of a clear egalitarian ideal and the presence of strong pressure on schools to become more effective, leads to competitive rather than collaborative relations between them. (12).

Such competition between schools produces the situation in which certain school institutions with the necessary capacity to participate in this market game adapt their educational technologies, pedagogical approaches and ideologies, organizational models to the practices of the most competitive schools. But this also implies a significant dose of external institutional influences such as school reputation, based on pupil intake and pupil performance, and degree of competition in the given local territory, which is connected to the demographic situation, parental expectations and strategies and applied policies concerning autonomy and choice.

As a result of such market positioning within the educational sphere in many countries, a hierarchical pyramidal structure of school education is formed with clearly defined lines of public favoritism and exclusion. At the top are schools that have a high, well-established reputation and are hardly affected by competition. Their main strategy consists in maintaining the external and internal factors that have created their reputation, such as selection, strong learning expectations or severe discipline. Their privileged position (not as an expression of better financial support, but as a constellation of the above factors) can be illustrated by the example of Bulgaria, where a given type of school institutions are qualified as elite.

Schools with a good reputation that start losing students will develop 'conquering strategies', that is, entrepreneurial, externally oriented practices. They will focus on developing attractive school provision and on 'scanning' the potential market, sometimes neglecting internal pressures (13). In the further downward movement within these reputational rankings, academically and socially heterogeneous schools will develop their own specific strategy trying to attract both the students - representatives of middle-class and some other categories of pupils, such as capable children from low-status families, children from minority families with more solid cultural capital, etc. Further down will be those schools that are mainly oriented towards low-status categories of students belonging to families with poorer cultural and educational capital, with low aspirations and possible behavioral problems. At the bottom of the hierarchy will be "ghetto" schools, often segregated on an ethno cultural basis, demonstrating a significant distance from existing school market mechanisms at the local level, and focus mainly on helping children with learning and discipline problems through specific supportive procedures and pedagogic interventions.

Such a hierarchical arrangement of schools, directly reflecting on the educational trajectories of the students taught in them, causes serious imbalances in the course of social mobility and significant differences in professional and, more broadly, social realization for the representatives of different strata and groups of society. Usually, such a scenario is typical for countries that adhere to „weak" versions of equality of opportunity in education, which are incrementalist in nature, they demand a greater or lesser extent of manipulation of resources, provision, organization, and priorities within the existing meritocratic and highly competitive structure of the educational system.

Significantly more successful in terms of increasing the educational chances of children from low-status groups are the attempts of countries that adhere to another (radical) approach. Within this approach, education is regarded as an agent for the reproduction and legitimation of the culture, interests and the power of dominant groups. The main intention is related to reconstructing the institutional structure and fight against the didactic approaches and competitive individualism within an achievement-orientated learning environment with an emphasis on student participation and responsibility for learning, genuine collaboration, and group-centered approaches (14). A number of data from international studies show that such an orientation in the field of education allows 
achieving a significant reduction in the differences in academic achievements between excellent students and those with the lowest results.

Bulgarian case of school segregation Against the background of these countries and even compared to the average levels for the OECD and EU countries, Bulgaria stands out with a very strong relationship between the educational results of students and their socioeconomic origin. For comparison, in the OECD countries almost a third (30.5\%), and in Bulgaria, $59.7 \%$ of the differences between student outcomes are due to factors of the school environment - school management, teacher qualifications, school resources, the socioeconomic and cultural background of the students, etc. $(15,16)$. It is clear that in Bulgaria, students are more dependent on their parents' income and social status than their peers in most European countries, including those with poorer economic conditions such as Albania. Income inequality and differences in the professional and educational status of parents prove to be a great burden for students. The data show that the difference between children with low-skilled parents and those with high-skilled parents is 2.5 years. And when it comes to disadvantaged children, the situation seems even more worrying. In turn, the specifics of the grouping of schools in Bulgaria, which is characterized by an obvious tendency to the homorganic composition of students and respectively, the dominant presence of students of the same socio-economic origin, further enhances the negative effect of low socio-economic status on children's educational trajectories.

Ultimately, the systematically reported large differences between the results of students with different backgrounds, which are consistently observed at all stages of PISA, as well as the applied policies of selection and distribution of students show that the Bulgarian school system, along with the socio-economic origin of students, contributes to the deepening of educational inequalities. In this way, the institutional system of school education not only reproduces the existing social structure of Bulgarian society with its inherent large-scale social inequality but even strengthens it. The real scale of social inequality in the country is eloquently evidenced by the latest statistics on poverty in 2019 , according to which Bulgaria has the highest share of people at risk of poverty and social exclusion in the EU $32.5 \%$, and for persons under 17 it amounts to $33.9 \%$. Moreover, if we look at the main indicators by ethnic groups (Table 1), poverty remains highly ethnicized (the situation is clearly maintained throughout the past years of transition) with a sharply outlined minority (and especially Roma) profile.

The only chance for the children from the Roma minority community to get out of the poverty trap is to get an education, to achieve a higher level of education. But even with the increase in the coverage of these children in the school system, inequality does not decrease precisely as a result of educational segregation. And the main explanation for this is that schooling is not the same as learning. (17).

Table 1. Estimates of some key indicators by ethnic groups in 2019

\begin{tabular}{|c|c|c|c|c|}
\hline \multirow[b]{2}{*}{ Indicators } & \multirow[b]{2}{*}{ Relative share - \% } & \multirow[b]{2}{*}{ Standard error } & \multicolumn{2}{|l|}{ Confidence interval } \\
\hline & & & $\begin{array}{l}95 \% \text { lower limit, in } \\
\text { percent }\end{array}$ & $\begin{array}{l}95 \% \text { upper limit, } \\
\text { in percent }\end{array}$ \\
\hline \multicolumn{5}{|c|}{ Population at risk of poverty and social exclusion and ethnicity } \\
\hline Bulgarian ethnic group & 18.6 & 0.9 & 17.0 & 20.4 \\
\hline Turkish ethnic group & 38.5 & 3.5 & 31.8 & 45.6 \\
\hline Roma ethnic group & 82.6 & 3.5 & 74.6 & 88.5 \\
\hline Another ethnic group & 18.4 & 7.9 & 7.5 & 38.6 \\
\hline \multicolumn{5}{|c|}{ Risk of poverty and ethnicity } \\
\hline Bulgarian ethnic group & 16.7 & 0.6 & 15.5 & 18.0 \\
\hline Turkish ethnic group & 31.6 & 2.5 & 26.9 & 36.6 \\
\hline Roma ethnic group & 64.8 & 3.8 & 57.0 & 71.9 \\
\hline Another ethnic group & 21.5 & 7.2 & 10.6 & 38.9 \\
\hline \multicolumn{5}{|c|}{ Material deprivation and ethnicity } \\
\hline Bulgarian ethnic group & 14.8 & 0.6 & 13.7 & 16.0 \\
\hline Turkish ethnic group & 22.1 & 2.3 & 17.9 & 27.0 \\
\hline Roma ethnic group & 63.0 & 3.9 & 55.1 & 70.2 \\
\hline Another ethnic group & 13.3 & 5.2 & 5.9 & 27.3 \\
\hline
\end{tabular}

Source: National Statistical Institute https://www.nsi.bg/bg/content/8258 
Erosion of learning exacerbates inequality: it seriously hobbles the disadvantaged children, who are most in need of the impetus that a good education can offer. Difficulties are generated from the first steps to the education system. The poor developmental foundations and lower levels of pre-school skills resulting from deprivation mean Roma children arrive at school unprepared to benefit fully from it (18, 19).

But when, in addition to a low level of preschool preparation, these children are faced with the inability to learn effectively in a homogenized environment, and to this is possibly added a lack of learning-focused inputs, ineffective teaching and incompetent management, the quality of education is called into question. At the same time, in the absence of real training and adequate knowledge, the opportunities for subsequent realization of individuals are drastically reduced, which in the long run leads to an increase in income inequality and a lower degree of social mobility among the population.

Undoubtedly, one of the most significant points here is related to the role of teachers. As noted in the research literature, the teacher is the most important factor affecting learning in schools. In the United States, for example, students with great teachers advance 1.5 grade levels or more over a single school year, compared with just 0.5 grade levels for those with an ineffective teacher $(20,21)$.

The situation in Bulgaria is similar: it is no coincidence that the highest educational results are demonstrated by students from the socalled elite schools, where due to the selected composition of students and high prestige of the schools, usually teach the most qualified teachers. The situation in "Roma" schools is much different. They are often seen as quite unattractive places for professional realization by teachers, which causes an outflow of the most trained staff. Besides, the presence of a number of non-specific problems and difficulties arising in the process of educational work become additional challenges and demotivating factors for the pedagogical specialists left to work there.

Practically every fifth Bulgarian junior high school teacher works in a school where for more than half of the students the Bulgarian language is not their mother tongue. This fact is a very serious challenge for the teachers in these schools, who presumably have to conduct the teaching process in Bulgaria (16) In addition, the predominant number of students in these schools comes from socially disadvantaged families, which further complicates the work of teachers and often leads to the need for them to perform functions that are not inherent in their professions, aimed to compensate some deficits in the family environment.

This imposed excessive focus mainly on helping children with learning and discipline problems along with an insufficient level of teaching experience and competencies leads to neglect of learning-focused inputs, and hence to a low quality of teaching. Well, known enough, that effective teaching strategies usually suppose targeting teaching to the level of the student includes using community teachers to provide lessons to the lowest performers, reorganizing classes by students' ability, or using technology to adapt lessons to individual student needs. But in most cases, such ethnicized schools do not have sufficient organizational, managerial and motivational resources to implement these profitable strategies.

Ineffective teaching here is often superimposed on ineffective school leadership, which means that school principals are not actively involved in helping teachers solve problems, do not provide instructional advice, and do not set goals that prioritize learning (22). This in turn closes the negative circle of barriers and restrictions on access to quality education for the most disadvantaged students.

\section{CONCLUSION}

Educational inequality in the field of school communities has become one of the sustainable institutions of post-communist Bulgaria, and the plans to modernize the system of school education probably do not involve (outside the realm of political rhetoric) deconstruction of these inequalities. And although the development of inequalities in education is rightly associated with an objective and inescapable contradiction inherent in the learning process itself, which is expressed in the conflict between public and individual interests, the admissibility of public intervention through education in the private life of citizens (23), the specifics of the current socio-cultural and educational situation requires a more tangible equalization of 
educational opportunities both in Bulgaria and in most other countries around the world.

Many successful school practices show that a number of interventions, innovations, and approaches have led to significant improvements in training. These promising approaches are offered in a very wide variability and cover new pedagogical methods, ways to increase the motivation of students and teachers, models of effective school management, and various technologies for improving learning. They may not be fully applicable in all contexts, but the fact that such an improvement in learning outcomes is possible, especially for children from disadvantaged social groups, as the experience of some countries shows, seems encouraging.

\section{REFERENCES}

1. Becker, G., The human capital: A theoretical and empirical analysis with special reference to education. 3d ed. Chicago: The University of Chicago Press, USA, 1993.

2. Earl, D., How can tertiary education deliver better value to the economy? Tertiary education occasional paper 2010/08, New Zealand Government, Ministry of Education, 2010, Accessed 05.05.2020, ISSN 1179-5026 (online) from

https://www.educationcounts.govt.nz/_data/ass ets/pdf_file/0004/86980/value-of-tertiaryeducation.pdf).

3. Sewell, W.H., Shah, V.P., Socioeconomic Status, Intelligence, and the Attainment of Higher Education, Sociology of Education, Vol. 40, 1:1-23, 1967.

4. Sewell, W.H., Haller, A.O., Portes, A., The Educational and Early Occupational Attainment Process, American Sociological Review, Vol. 34, 1:82- 92, 1969.

5. Coleman, J. S., The Equality of Education Opportunity Report, Washington, DC: Government Printing Office, USA, 1966.

6. Coleman, J. S., The University and the Society's New Demands Upon It // Content and Context on College Education. Ed. by C. Kaysen. New-York: Mc Graw-Hill, P. 359-400, 1973.

7. Gamoran, A., The stratification of high school learning opportunities. Sociology of Education, Vol. 60, 3:135-155, 1987.

8. Oakes, J., Keeping track: How schools structure inequality (2nd edition). Yale University Press, ISBN 0300108303, New Haven, CT, 2005.

9. Purkey, S., Smith, M., Effective schools: a review, Elementary School Journal, 83:427-52, 1983.

10. World Bank, World Development Report 2018: Learning to Realize Education's Promise. Washington, DC: World Bank. (C) World Bank, 2018, Accessed 05.05.2020, (online) from https://openknowledge.worldbank.org/handle/10 986/28340.

11. Thrupp, M., Schools Making a Difference: let's be realistic! Buckingham: Open University Press, 1999.

12. Van Zanten, A., New Modes of Reproducing Social Inequality in Education: the changing role of parents, teachers, schools and educational policies, European Educational Research Journal, Vol. 4, 3:155-169, 2005.

13. Bagley, C., Woods, P., Glatter, R., Scanning the Market: school strategies for discovering parental perspectives, Educational Management and Administration, Vol. 24, 2:125-138, 1996.

14. Troyana, B., A conceptual overview of strategies to combat racial inequality in education: introductory essay, pp.1-10, Racial Inequality in Education, edited by Troyana Burry, Tavistock Publications, London, 1987.

15. Prirodnie nauki I tehnologii $\mathrm{v}$ uchilishteto na XXI vek. Rezultati ot uchastieto na Bulgaria v Programata za mezhdunarodno otsenyavane na uchenitsite PISA 2015, CKOKO, Sofia 2016, Accessed 05.05.2020, (online) from http://www.copuo.bg/upload/docs/201612/book_2016_web.pdf.

16. Perspektivi pred prepodavaneto i ucheneto, rezultati ot Mezhdunarodno izsledvane TALIS 2013 na Organizatsiyata za ikonomichesko satrudnichestvo i razvitie, CKOKO, Sofia 2015, Accessed 05.05.2020, (online) from http://www.copuo.bg/upload/docs/201509/BG_Report_final_TALIS_2015.pdf.

17. Pritchett, L., The Rebirth of Education: Schooling Aren't Learning. Washington, DC: Center for Global Development; Baltimore: Brookings Institution Press, 2013.

18. Paxson, C. and Schady N., Cognitive Development among Young Children in Ecuador: The Roles of Wealth, Health, and Parenting, Journal of Human Resources 42 (1): 49-84, 2007.

19. Schady, N., Behrman, J., Caridad M., Azuero, R. et al., Wealth Gradients in Early Childhood Cognitive Development in Five Latin American Countries, Journal of Human Resources 50 (2): 446-63, 2015.

20. 20. Hanushek, E., The Trade-Off between Child Quantity and Quality, Journal of Political Economy 100 (1): 84-117, 1992.

21. Rockoff, J. (2004). "The Impact of Individual Teachers on Student Achievement: Evidence from Panel Data." American Economic Review 94 (2): 247-52.

22. Orazem, P., Glewwe, P., Patrinos, H., The Benefits and Costs of Alternative Strategies to Improve Educational Outcomes, Department of Economics Working Paper 07028, Iowa State University, Ames, 2007.

23. Jarvis, P., Paradoxes of Learning. On becoming an Individual in Society, L.: Routledge, 2012. 